\title{
THE IMPACT OF PRECIPITATION CONDITIONS ON MEDIUM-EARLY CULTIVARS OF POTATO YIELDING
}

\author{
Katarzyna Rymuza', Elżbieta Radzka', Tomasz Lenartowicz² \\ 1 Siedlce University of Natural Sciences and Humanities, Prusa 14, 08-110 Siedlce, Poland, e-mail: katarzyna. \\ rymuza@uph.edu.pl \\ 2 The Research Centre for Cultivar Testing in Słupia Wielka, 63-022 Słupia Wielka, Poland
}

Received: 2015.03 .15

Accepted: 2015.06 .02

Published: 2015.07.01

\begin{abstract}
This elaboration was based on yields of nine medium-early cultivars of potato grown in Karżniczka station belonging to COBORU(Research Centre for Cultivar Testing) and on monthly precipitation sums during the growing season (April - August). For each of the cultivars separately in subsequent years and for precipitation sums in particular months of the growing season (IV-VII) polynomial regression models of precipitation - cultivar's yield - were calculated. At the beginning of the growing season the yield of medium-early cultivars of potato was negatively correlated with monthly precipitation sums, while in the final stage of vegetation - this correlation was positive. The lowest yield of Stasia cultivar was noted with monthly precipitation sum of 34-38 mm in April, Tajfun cultivar with May precipitation from 100 to $120 \mathrm{~mm}$, Finezja and Jurek cultivars with monthly June precipitation of $120 \mathrm{~mm}$. Whereas maximum yield of Cekin and Jurek cultivars was noted with August precipitation of about $100 \mathrm{~mm}$.
\end{abstract}

Keywords: medium-early cultivars, yield, potato, precipitation.

\section{INTRODUCTION}

Root crops have high water demands due to long growing season, large amount of biomass produced and weaker root system than in other plants [Dzieżyc et. al. 1987; Nowak 2006a, 2006b; Rębarz and Borówczak 2006; Trawczyński 2009]. The highest impact on potato growth, development and yielding has agronomic treatment as well as the weather, especially the amount and distribution of precipitation [Nowak 2006]. Periods of evident sensitivity to water deficiency for early potato cultivars fall in June and early July [Głuska 2000 and 2004], while for medium-late and late cultivars - in July and first decade of August [Biniak et. al. 2007, Kalbarczyk 2005]. Early cultivars are particularly sensitive to water deficiency due to intensive growth of aerial parts and rapid increase in tuber [Sawicka and KrochmalMarczak 2005, Dzieżyc et. al. 2012]. The list of cultivars of agricultural plants includes many po- tato cultivars in particular earliness groups. They differ not only in rhythm of development, length of the growing season, but most of all, in utility features. This creates a possibility of their widespread use in practice. Many cultivars in natural way fall out of the register. Their place is taken by the new ones. Both the new and already existing cultivars show different reactions to variable growing conditions [Dmowski et. al. 2004].

The aim of this study was to define the impact of monthly precipitation sums during the growing season on yield of medium-early potato cultivars.

\section{MATERIALS AND METHODS}

Material constituted the results of longterm field trials (2010-2013) and meteorological observations coming from Cultivars Assessment Station Karżniczka belonging to COBORU. Experiments with medium-early potato 
cultivars were performed in incomplete blocks system on the soil of good wheat complex. The surface of the plots was $15 \mathrm{~m}^{2}$. Potatoes were planted in the third decade of April with a spacing of $75 \mathrm{~cm}$ and distance between furrows in a row of $33 \mathrm{~cm}$. They were collected in a period of full maturity. Fertilization was used according to principles of COBORU methodology. During the experiments full plants protection against potato blight, Colorado potato beetle and against weeds was used.

Cultivars selected for the analysis were tested in experiments in all four years of the studies (2010-2013). For each cultivar separately based on yields received from repetitions (plots) in subsequent years and on precipitation sum in particular months of the growing season (IV - VIII) polynomial regression models precipitation - cultivar's yield were calculated. This study includes only these models which in significant way (when $\mathrm{p} \leq 0,05)$ described the above mentioned relations. All the calculations were performed using STATISTICA 10.0.

\section{RESULTS AND DISCUSSION}

Yield of medium-early potato cultivars was negatively correlated with monthly precipitation sums at the beginning of the growing season and positively - in the second part of vegetation (Table 1). Yielding of Stasia cultivar was significantly dependent on April precipitation, Satina and Tajfun cultivars - on May precipitation, Finezja and Jurek cultivars - on June precipitation. Increase in monthly precipitation sums in July significantly influenced the increase in yield of Ametyst, Oberon and Stasia cultivars. Whereas increase in yielding of Jurek and Cekin cultivars occurred together with increasing precipitation in August. In the first stages of development, potato plants use water supplies of winter in the soil, therefore, high precipitation in the period from March to May can have negative influence on quality and quantity of the yields. The period of setting the flower budsuntil the end of flowering is a period of increased sensitivity of the plant to water factor [Jakubowski 2007]. It was stated that in May and June there is an excess of precipitation in comparison to water demands of potato across the whole country in the multi-year on average. Mean multi-year precipitation sum in these months in Poland is respectively higher of 15 and $11 \mathrm{~mm}$ than the optimal value [Kalbarczyk and Kalbarczyk 2009].

Polynomial regression analysis describing the relationship between monthly precipitation sums and the yield of the analyzed cultivars revealed that yielding of seven out of nine of the analyzed cultivars depended on precipitation during the growing season (Table 2). Regression equations for Ametyst and Oberon cultivars covered only precipitation sums in July, for Satina and Tajfun cultivars - in May and for Finezja in June. Only for Jurek and Stasia cultivars the equations describing their yielding relationship with precipitation covered precipitation sums of two months. For Jurek cultivar it was June and August precipitation, while for Stasia - April and July.

The lowest yield of Stasia cultivar about 450 $\mathrm{dt} \cdot \mathrm{ha}^{-1}$ was observed with monthly precipitation sum in April around the level of 34-38 mm (Figure 1). More unfavorable in this month could be the excess of water because it may result in rotting of tubers [Rolbiecki et al. 2009].

Table 1. Correlation coefficients values between monthly precipitation sums and the yield of the analyzed cultivars

\begin{tabular}{|c|c|c|c|c|c|}
\hline \multirow{2}{*}{ Cultivar } & \multicolumn{3}{|c|}{ Month } & June & July \\
\cline { 2 - 6 } & April & May & -0.340 & $0.910^{*}$ & 0.264 \\
\hline Ametyst & -0.109 & -0.130 & -0.525 & 0.502 & $0.648^{*}$ \\
\hline Cekin & -0.133 & 0.164 & $-0.620^{*}$ & 0.348 & 0.429 \\
\hline Finezja & -0.381 & -0.232 & -0.373 & 0.476 \\
\hline Gawin & -0.291 & 0.111 & $-0.596^{*}$ & 0.255 & $0.595^{*}$ \\
\hline Jurek & -0.506 & 0.0128 & -0.362 & $0.908^{*}$ & 0.516 \\
\hline Oberon & -0.566 & -0.167 & -0.111 & 0.253 \\
\hline Satina & 0.526 & $-0.635^{*}$ & 0.105 & -0.115 \\
\hline Stasia & $-0.707^{*}$ & -0.098 & -0.367 & 0.371 \\
\hline Tajfun & 0.477 & $-0.889^{*}$ & & -0.345 \\
\hline
\end{tabular}

\footnotetext{
* correlation significant when $\mathrm{p} \leq 0,05$.
} 
Table 2. Polynomial regression equations describing the relationship between monthly precipitation sums and yield of the analyzed cultivars

\begin{tabular}{|c|c|l|}
\hline Cultivar & Month & Polynomial regression equation \\
\hline Ametyst & July & $\mathrm{y}=0,01 \mathrm{x}^{2}-1,69 \mathrm{x}+635,21$ \\
\hline Finezja & June & $\mathrm{y}=0,1047 \mathrm{x}^{2}-25,38 \mathrm{x}+1713,68$ \\
\hline \multirow{2}{*}{ Jurek } & June & $\mathrm{y}=0,09 \mathrm{x}^{2}-23,56 \mathrm{x}+1655,8$ \\
\cline { 2 - 3 } & August & $\mathrm{y}=-0,05 \mathrm{x}^{2}-11,14 \mathrm{x}+123,52$ \\
\hline \multirow{2}{*}{ Oberon } & July & $\mathrm{y}=0,01 \mathrm{x}^{2}-1,69 \mathrm{x}+635,21$ \\
\hline \multirow{2}{*}{ Stasia } & April & $\mathrm{y}=1,14 \mathrm{x}^{2}-80,92 \mathrm{x}+1895,60$ \\
\cline { 2 - 3 } & July & $\mathrm{y}=0,02 \mathrm{x}^{2}-4,25 \mathrm{x}+739,96$ \\
\hline \multirow{2}{*}{ Satina } & May & $\mathrm{y}=806,76-3,98 \mathrm{x}$ \\
\hline Tajfun & May & $\mathrm{y}=730,09-0,87 \mathrm{x}-0,001 \mathrm{x}^{2}$ \\
\hline
\end{tabular}

Yield of Satina cultivar decreased linearly along with an increase in monthly precipitation sums in May (Figure 2). Whereas the lowest yield (about $600 \mathrm{dt} \cdot \mathrm{ha}^{-1}$ ) of Tajfun cultivar was observed with May precipitation ranging from 100 to $200 \mathrm{~mm}$.

Minimum yield of Finezja and Jurek cultivars (respectively: about $180 \mathrm{dt} \cdot \mathrm{ha}^{-1}$ and $250 \mathrm{dt} \cdot \mathrm{ha}^{-1}$ ) was obtained with monthly precipitation sum in June of $120 \mathrm{~mm}$ (Figure 3). When precipitation sums in this month were higher, yield of both cultivars increased.

Low precipitation sums in July: till about $80 \mathrm{~mm}$ for Ametyst and Oberon cultivars, and about $100 \mathrm{~mm}$ for Stasia cultivar shaped their yielding at a low level (Figure 4). An increase in precipitation sum in this month resulted in gradual increase in yielding of all three cultivars. It was stated that potato responds strongly to moisture conditions improvement [Mazurczyk et. al. 2009, Rolbiecki et. al. 2009, Rzekanowski et. al. 2004, Żarski 2011]. High precipitation demands of potato in July wasestimated from 78 to $120 \mathrm{~mm}$, as observed by Dzieżyc et. al. [1987], Głuska [2004] and Kalbarczyk [2005].

Increase in precipitation sum in August resulted in yielding increase of Cekin and Jurek cultivars (Figure 5). Maximum yield of both cultivars (respectively: about $650 \mathrm{dt} \cdot \mathrm{ha}^{-1}$ and 670 $\mathrm{dt} \cdot \mathrm{ha}^{-1}$ ) was noted with precipitation of about 100 $\mathrm{mm}$. Further increase in precipitation resulted in yielding decrease of the analyzed potato cultivars. According to Lutomirska [2005], the final stage of the growing season which is the period of drying of haulm and collecting of tubers is characterized by lower water requirements.

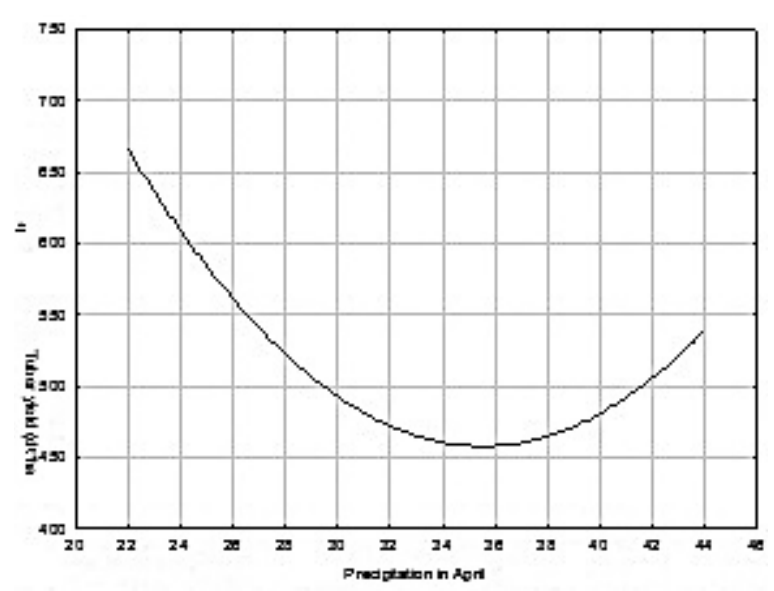

Figure 1. Dependency graph between yielding of Stasia cultivar and mean precipitation sum in April

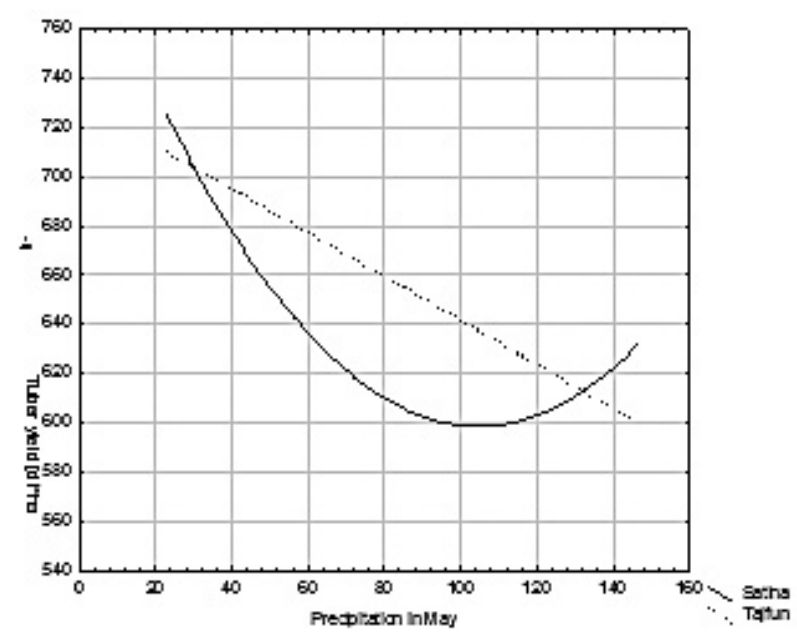

Figure 2. Dependency graph between yielding of Satina and Tajfun cultivars and mean precipitation sum in May

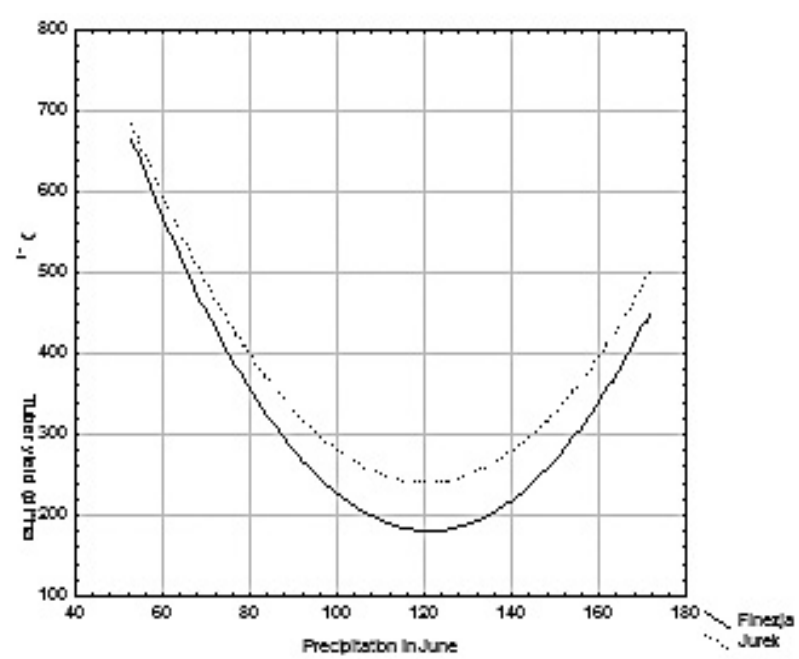

Figure 3. Dependency graph between yielding of Finezja and Jurek cultivars and mean precipitation sum in June 


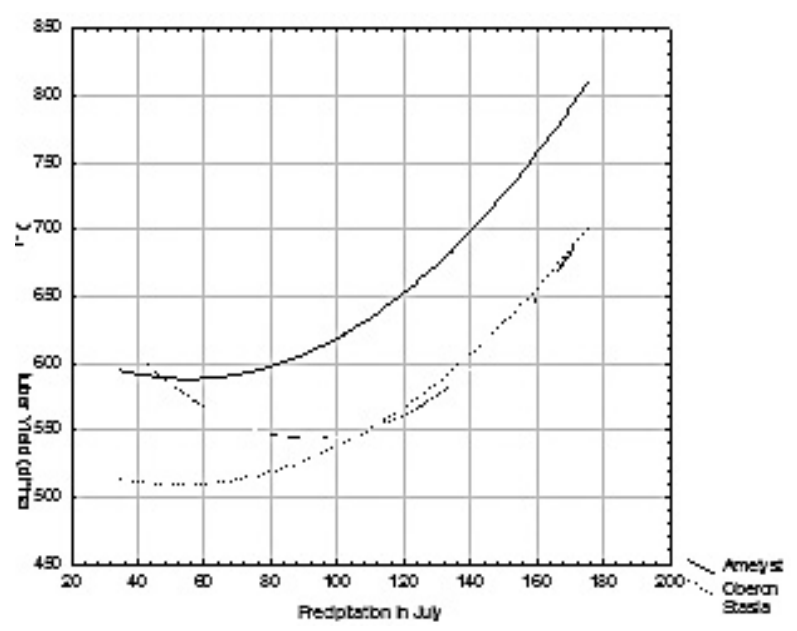

Figure 4. Dependency graph between yielding of Ametyst, Oberon and Stasia cultivars and mean precipitation sum in July

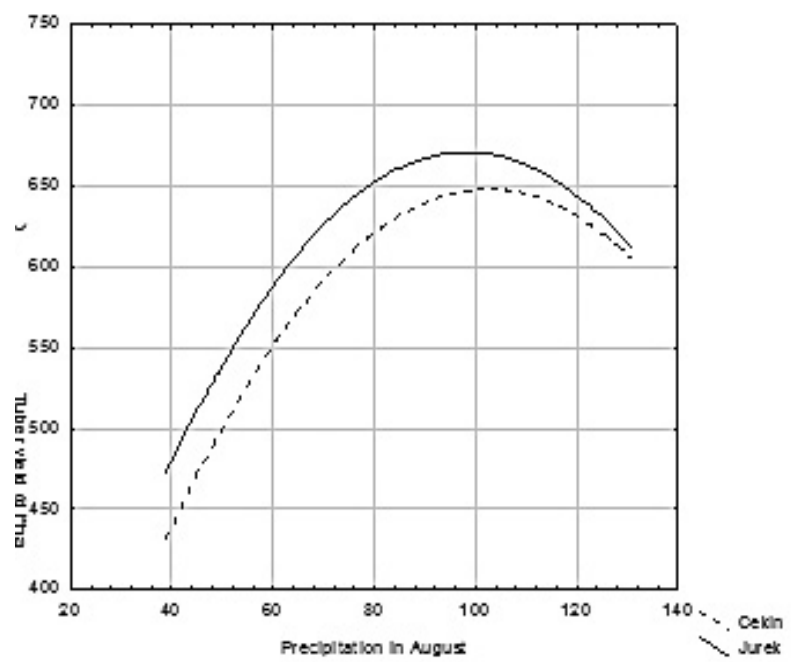

Figure 5..Dependency graph between yielding of Cekin and Jurek cultivars and mean precipitation sum in August

\section{CONCLUSIONS}

1. Yield of medium-early potato cultivars was negatively correlated with monthly precipitation sums at the beginning of the growing season, and positively correlated - in the final stage of vegetation.

2. Yielding of Satina and Tajfun cultivars was correlated with May precipitation, of Ametyst and Oberon cultivars - July, and of Jurek and Satina cultivars respectively - June, August and April, July.

3. The lowest yield of Stasia cultivar (about 450 $\mathrm{dt} \cdot \mathrm{ha}^{-1}$ ) was noted with monthly precipitation sum in April of 34-38 mm, Tajfun cultivar (about $600 \mathrm{dt} \cdot \mathrm{ha}^{-1}$ ) with May precipitation ranging from 100 to $120 \mathrm{~mm}$, and Finezja and Jurek cultivars (respectively: about $180 \mathrm{dt} \cdot \mathrm{ha}^{-1}$ and $250 \mathrm{dt} \cdot \mathrm{ha}^{-1}$ ) with monthly precipitation sum in June of $120 \mathrm{~mm}$. Maximum yield of Cekin and Jurek cultivars (respectively: about $650 \mathrm{dt} \cdot \mathrm{ha}^{-1}$ and $670 \mathrm{dt} \cdot \mathrm{ha}^{-1}$ ) was observed with August precipitation of about $100 \mathrm{~mm}$.

\section{REFERENCES}

1. Biniak M., Kostrzewa S., Żyromski A., 2007. Uwarunkowania termiczne i opadowe potrzeb wodnych w rejonie Wrocławia na przykładzie ziemniaków średnio późnych. Zesz. Probl. Post. Nauk Rol., 519, 31-45.

2. Dmowski Z., Nowak L., Chmura K., 2004. Reakcja odmian ziemniaka o różnej długości wegetacji na zróżnicowane warunki wodno-nawozowe. Biul. IHAR, 232, 141-148.

3. Dzieżyc H., Chmura K., Dmowski Z., 2012. Określenie wpływu warunków opadowych na plonowanie ziemniaka bardzo wczesnego i wczesnego w południowej Polsce. Woda-Środowisko-Obszary Wiejskie, 12(2), 133-141.

4. Dzieżyc J., Nowak L., Panek K., 1987. Dekadowe wskaźniki potrzeb opadowych roślin uprawnych w Polsce. Zesz. Probl. Post. Nauk Roln., 314, 11-33.

5. Głuska A., 2000. Nawadnianie jako czynnik kształtujący jakość plonu ziemniaka. Biuletyn IHAR, 213, 179-184.

6. Głuska A., 2004. Wpływ zmiennego rozkładu opadów na cechy bulw ziemniaka (Solanum tuberosum L.) oraz wyznaczenie okresu krytycznego wrażliwości na niedobór wody u odmian o różnej długości okresu wegetacji. Zesz. Probl. Post. Nauk Rol., 496, 217-227.

7. Jakubowski T., 2007. Potato tuber cropping and susceptibility to mechanical damage related to hydrothermal coefficient. Inżynieria Rol., 8(96), 87-93.

8. Kalbarczyk R., 2005. Strefy klimatycznego ryzyka uprawy ziemniaka późnego w Polsce. Folia Univ. Stetin. Agricultura, 244 (99), 83-90.

9. Kalbarczyk R., Kalbarczyk E., 2009. The needs and deficiency in atmospheric precipitation in cultivated mid-late and late potato in Poland. Infrastructure and Ecology of Rural Areas, 3, 129-140.

10. Lutomirska B., 2005. Wpływ temperatury w pełni sezonu wegetacji na plon ziemniaka. Ziemniak Polski, 4, 14-15.

11. Mazurczyk W., Wierzbicka A., Wroniak J., 2009. Wpływ optymalizacji nawadniania i nawożenia azotem na wybrane parametry wzrostu roślin oraz 
plon wczesnej odmiany ziemniaka. Infr. i Ekol. Terenów Wiejskich, 3, 91-100.

12. Nowak L., 2006a. Potrzeby wodne roślin okopowych. In: S. Kaczmarczyk. L. Nowak. (Ed.) Nawadnianie roślin. PWRiL Poznań, 368-372.

13. Nowak L., 2006b. Nawadnianie roślin okopowych. In: S. Kaczmarczyk. L. Nowak. (Ed.) Nawadnianie roślin. PWRiL Poznań, 367-381.

14. Rębarz K., Borówczak F., 2006. Wpływ deszczowania, technologii uprawy i nawożenia azotowego na wielkość bulw, plon handlowy i występowanie strat w czasie przechowywania ziemniaków. Rocznik AR w Poznaniu - Rolnictwo, 66, 305-313.

15. Rolbiecki S., Rzekanowski Cz., Rolbiecki R., 2009: Ocena potrzeb i efektów nawadniania ziemniaka średnio wczesnego w okolicy Bydgoszczy w latach 2005-2007. Acta Agrophysica, 13(2), 463-472.
16. Rzekanowski C., Rolbiecki S., Rolbiecki R., 2004. Productive results of sprinkler irrigation of potatoes on the light soils in central Poland. Agricultural Engineering XLI, 2, 56-60.

17. Sawicka B., Krochmal-Marczak B., 2005. Wpływ czynników agrometeorologicznych na długość faz rozwojowych bardzo wczesnych i wczesnych odmian ziemniaka. Acta Agrophysica, 6(1), 225-236.

18. Tomaszewska T., 1972. Wpływ warunków meteorologicznych na plon i zawartość skrobi ziemniaków. Przeg. Geofiz., 3-4, 261-289.

19. Trawczyński C., 2009. Wpływ nawadniania kroplowego i fertygacji na plon i wybrane elementy jakości bulw ziemniaka. Infrast. Ekol. Ter. Wiej., 3, 55-67.

20. Żarski J., 2011. Tendencje zmian klimatycznych wskaźników potrzeb nawadniania roślin w rejonie Bydgoszczy. Infrast. i Ekol. Ter. Wiej., 5, 29-37. 